\title{
'n Model vir 'n aanlyn GIS-vakwoordeboek
}

\author{
Lize-Mari Theron, Departement Afrikaans en Nederlands, \\ Universiteit Stellenbosch, Suid-Afrika (theronlizemari@gmail.com)
}

Opsomming: As deel van 'n MA-studie aan die Universiteit Stellenbosch, is 'n model vir ' $n$ aanlyn GIS-vakwoordeboek ontwikkel om drie probleme aan te spreek. Die eerste probleem is die groot hoeveelheid vakwoordeboeke wat gemaak is sonder die leiding van die leksikografieteorie. Dit is min dat ' $n$ woordeboek sy potensiaal van gebruikersvriendelikheid en toeganklikheid bereik sonder die leiding van die leksikografieteorie. 'n Vakgebied wat hierdie probleem het, is Geografiese Inligtingstelsels (GIS). As daar na aanlyn GIS-vakwoordeboeke gekyk word, word die tweede probleem geïdentifiseer: die bestaande GIS-vakwoordeboeke is nie genoegsame bronne vir GIS-pedagogie in Suid-Afrika nie. Die bestaande vakwoordeboeke is nie gemik op enige spesifieke gebruiker nie. Beginners, semi-deskundiges en deskundiges se onderskeie, spesifieke behoeftes word nie in ag geneem nie. Daar is ook geen vakwoordeboek wat 'n operasionele funksie bied nie, almal fokus net op teksresepsie. 'n Verdere blik op die kommunikatiewe funksie van hierdie vakwoordeboeke, wys die derde probleem: daar is geen GIS-vakwoordeboek wat vertaalekwivalente in Afrikaans (of enige van die ander amptelike Afrikatale) bied nie. In hierdie artikel word daar 'n model voorgestel wat ontwikkel is met die leiding van die leksikografieteorie en wat die gaping in GISpedagogie in Suid-Afrika kan aanpreek, want dit is bedoel vir beginners en dit het beide 'n operasionele en kommunikatiewe funksie.

Sleutelwoorde: VAKWOORDEBOEKE, LEKSIKOGRAFIETEORIE, OPERASIONELE FUNKSIE, KOMMUNIKATIEWE FUNKSIE, GEOGRAFIESE INLIGTINGSTELSELS, VAKLEKSIKOGRAFIE, WOORDEBOEKMODEL, GIS-PEDAGOGIE, AANLYN WOORDEBOEKE, WOORDEBOEK-KOSEPTUALISERINGSPLAN, E-LEEROMGEWINGS, HIBRIDIESE WOORDEBOEKMODEL

Abstract: A Model for an Online Specialized Dictionary for GIS. As part of a MA study completed at Stellenbosch University, a model for an online specialized dictionary for GIS was developed to address three problems. The first problem is the large number of specialized dictionaries created without the guidance of the theory of lexicography. A dictionary seldom reaches its potential of user-friendliness and accessibility without the guidance of theory of lexicography. One field of study that has this problem is Geographic Information Systems (GIS). Looking at online GIS dictionaries, the second problem is identified: the existing specialized dictionaries for GIS are not sufficient sources for GIS pedagogy in South Africa. The existing dictionaries are not aimed at any specific user. Beginners, semi-experts and experts are all treated the same without taking into account their individualized needs. There is also no specialized dictionary that provides an operational function - all of the dictionaries focus only on text reception. A look at the communicative function of these specialized dictionaries shows the third problem: there is no GIS dictionary that offers translation equivalents in Afrikaans (or any of the other official African languages).

Lexikos 30 (AFRILEX-reeks/series 30: 2020): 499-518 
This article proposes a model developed with the theory of lexicography that can address the gap in GIS pedagogy in South Africa, as it is intended for beginners and has both an operational and a communicative function.

Keywords: SPECIALIZED DICTIONARIES, THEORY OF LEXICOGRAPHY, OPERATIONAL FUNCTION, COMMUNICATIVE FUNCTION, GEOGRAPHIC INFORMATION SYSTEMS, SPECIALIZED LEXICOGRAPHY, DICTIONARY MODEL, GIS PEDAGOGY, ONLINE DICTIONARIES, DICTIONARY CONCEPTUALIZATION PLAN, E-LEARNING ENVIRONMENTS, HYBRID DICTIONARY MODEL

\section{Inleidende opmerkings}

Daar is 'n probleem in die land van die leksikografie: daar is vakwoordeboeke wat saamgestel is sonder die leiding van die leksikografieteorie. Oor die afgelope twee dekades het die hoeveelheid gedrukte en aanlyn vakwoordeboeke vermenigvuldig, maar Tarp (2012: 118) bevraagteken die gehalte van hierdie vakwoordeboeke omdat baie van hulle sonder die insette van die leksikografieteorie gemaak is. 'n Aanlyn vakwoordeboek van gehalte moet, onder andere, gemaak word met die insette van die vakspesialis, die IT-tegnikus en veral die leksikograaf (Fuertes-Olivera en Tarp 2014: 197). As enige van hierdie drie komponente ontbreek, kan dit veroorsaak dat woordeboeke nie optimaal gebruikersvriendelik en toeganklik is nie (Fuertes-Olivera en Tarp 2014: 197), wat dit ook uiteraard moeilik sal maak om die gebruiker se behoeftes te bevredig.

'n Vakgebied waarvan die vakwoordeboeke problematies is, is Geografiese Inligtingstelsels (GIS). GIS is rekenaarapparatuur en -programmatuur wat gebruikers in staat stel om geografiese data te kan manipuleer, analiseer en visualiseer. 'n GIS kan gebruik word om 'n ingewikkelde, ruimtelike vraag soos: "Waar is die beste plek om ' $n$ boerekoöperasie in die Tankwa-Karoo te bou?" te antwoord op grond van, byvoorbeeld, geografiese data oor landbougemeenskappe, vervoerroetes, eiendom te koop, ensovoorts. GIS is 'n belangrike en relevante hulpmiddel in vandag se inligtingsgedrewe wêreld. Elke persoon wat vandag geografiese data op 'n kaart wil tipeer, kan dit doen met GIS-programmatuur wat gratis op die internet beskikbaar is. Tog is dit nie so eenvoudig nie, want GIS vereis 'n mate van kennis oor die GIS-wetenskap en ook goeie rekenaarvaardighede.

Omdat die meeste GIS-vakwoordeboeke sonder die leiding van die leksikografieteorie saamgestel is, is die probleem nou dat die beskikbare aanlyn vakwoordeboeke nie effektiewe bronne vir GIS-pedagogie is nie. Die bestaande vakwoordeboeke is, eerstens, nie gemik op enige spesifieke gebruiker nie. 'n Woordeboek moet met ' $n$ bepaalde gebruiker voor oog saamgestel word omdat 'n enkele woordeboek nooit alle behoeftes van alle gebruikers kan bevredig nie. Tweedens vervul hierdie vakwoordeboeke almal net 'n kommunikatiewe funksie, en daar is geen aandag gegee aan 'n operasionele funksie nie. 'n Funksie 
wat baie nodig is vir hierdie praktiese veld. Derdens is hierdie GIS-vakwoordeboeke ook verouderd in dié opsig dat hulle nie digitaal baie innoverend is nie. Digitale innovering is belangrik omdat dit woordeboeke in die nuwe medium (aanlyn) meer toeganklik en gebruikersvriendelik kan maak. 'n Moontlike oplossing vir hierdie probleem is 'n leksikografies gefundeerde, aanlyn GIS-vakwoordeboek.

As deel van ' $n$ MA-studie aan die Universiteit Stellenbosch is daar ' $n$ vakwoordeboek-model ontwikkel om hierdie probleem aan te spreek (Theron 2019). Hierdie studie het gepoog om aan die hand van die funksieteorie (wat fokus op die behoeftes van woordeboekgebruikers) en die algemene leksikografieteorie (wat handel oor woordeboekstrukture) ' $n$ model daar te stel wat onder meer voorstelle maak in verband met die funksies, inhoud en strukture vir 'n aanlyn vakwoordeboek. Die voorstelle sorg dat die teikengebruiker 'n optimale onttrekking van inligting uit die aangebode data kan hê.

Hierdie studie het bestaan uit drie take (Theron 2019). Die eerste taak was om die gebruikersbehoeftes met behulp van die funksieteorie te identifiseer. Die gebruikers is geïdentifiseer as derdejaarstudente aan die Universiteit Stellenbosch wat die Geografiese Kommunikasie-module ('n beginnerskursus in GIS) neem. Die tweede taak het die bestaande aanlyn GIS-vakwoordeboeke geëvalueer in 'n poging om goeie en swak kenmerke te identifiseer wat leiding kan bied vir toekomstige vakwoordeboeke. Die derde en laaste taak was om die bevindinge van die eerste twee take te gebruik om 'n model vir 'n nuwe, aanlyn GIS-vakwoordeboek te konseptualiseer. Hierdie artikel doen verslag van die laasgenoemde taak.

Die model wat in hierdie artikel daargestel word, is vir 'n aanlyn GIS-vakwoordeboek wat spesifiek op die studente van die Geografiese Kommunikasiemodule se behoeftes gemik is. Die gebruikersgroep is die groep derdejaarstudente wat, onder andere, Engels- en Afrikaanssprekend is. Die module word in Engels aangebied, maar Afrikaanse studente het die geleentheid om werkstukke in Afrikaans te skryf. Tog is daar die vermoede dat die meeste van die studente hul werkstukke in Engels skryf omdat hulle nie die regte vertaalekwivalente vir die Engelse vakterme het nie. Die model vir die GIS-vakwoordeboek is veronderstel om die Engelse lemmata te verklaar, wat kognitiewe steun vir studente sal bied, sowel as om Afrikaanse vertaalekwivalente te verskaf sodat die Afrikaanse studente hul akademiese opdragte in hul moedertaal kan skryf. Daarom stel hierdie model ' $n$ vakwoordeboek voor wat as ' $n$ hibridiese woordeboek getipeer kan word, want dit bevat aspekte van beide 'n vertalende en verklarende woordeboek.

Die model weerspieël 'n uiteindelike woordeboek wat geïntegreerd optree met die Geografiese Kommunikasie-module se studiemateriaal op die Universiteit Stellenbosch se SUNLearn-platform. Die elektroniese platform, SUNLearn, bied die moontlikheid om e-woordeboeke deel van e-leeromgewings te maak. As so 'n woordeboek geïntegreerd met die studiemateriaal optree, kan dit 'n positiewe invloed op die algemene woordeboekkultuur van die studente hê (Gouws 
2013: 59). So 'n geïntegreerde aanlyn vakwoordeboek is ook gepas vir die gebruikersgroep omdat die meeste van die GIS-take op 'n rekenaar (en op SUNLearn) voltooi moet word. Die model is geïnspireer deur die aanlyn GIS-vakwoordeboek van Esri (https://support.esri.com/en/other-resources/gis-dictionary/), die Duitse woordeboek elexiko (https://www.owid.de/wb/elexiko/start.html) en ook die PharosAanlyn- woordeboekversameling (https://www-pharosaanlynco-za.ez.sun.ac.za/tuis).

Hierdie artikel bespreek die belangrikste aspekte van hierdie model. Die term "model" word gebruik om te verwys na daardie voorbeeldvorm, as deel van die woordeboek-konseptualiseringsplan, wat nagevolg word in die opstel van ' $n$ bepaalde woordeboek (Gouws en Prinsloo 2005: 10). Daar sal aan die openingskerm, die toegangstruktuurelemente en die woordeboekartikels aandag gegee word. Daar sal ook na die nodige data-inskrywings, die geskikte ontwerp, die woordeboekstrukture, en digitale innovering gekyk word. Hierdie GIS-vakwoordeboek kan die gaping in GIS-pedagogie vul en dit kan ook dalk 'n positiewe invloed op die algemene woordeboekkultuur van die studente hê.

\section{Die model}

\subsection{Die basiese ontwerp}

Die voorstel is dat die GIS-vakwoordeboek deel vorm van die Universiteit Stellenbosch se studenteportaal, SUNLearn. Dit sal die vakwoordeboek meer toeganklik maak vir die studente. As die vakwoordeboek die Universiteit se naam dra, en sekere van die korporatiewe ontwerpsriglyne volg, sal die vakwoordeboek ook as betroubaarer beskou word. Hierdie ontwerpsriglyne sluit, byvoorbeeld, die gebruik van die kleure grys en maroen in. Die voorstel is ook om die vakwoordeboek in Engels te ontwikkel, aangesien dit ooreenstem met die modulewerk en die Universiteit se taalbeleid. Engels is die gekose taal van die Universiteit omdat dit beduidende nasionale, internasionale, akademiese en besigheids-gebruikswaarde het (Taalbeleid van die Universiteit Stellenbosch 2016: 2).

$\mathrm{Al}$ die afbeeldings is vir 'n rekenaarskerm ontwikkel. Die aanpassings wat vir 'n selfoonskerm gemaak sal moet word, sal nie hier bespreek word nie. Die basiese ontwerp van die vakwoordeboek is 'n webtuiste gestroop van kantpanele met net 'n stel permanente kenmerke bo-aan elke webbladsy (sien afbeelding 1). 


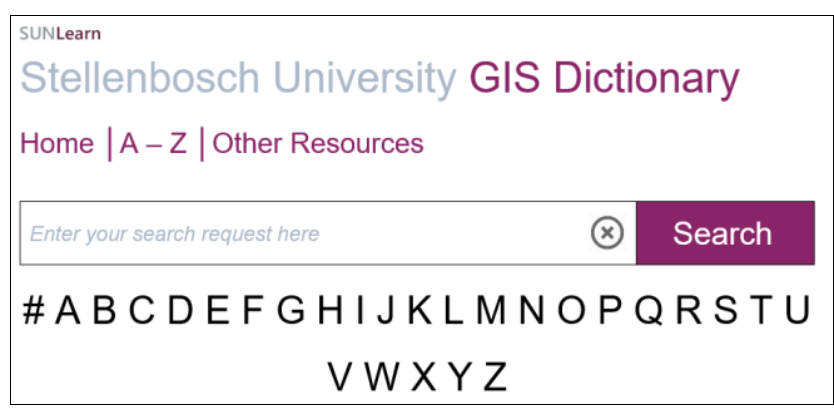

Afbeelding 1: Die permanente kenmerke bo-aan elke webbladsy van die vakwoordeboek

Hierdie permanente kenmerke bestaan uit (1) die vakwoordeboek se naam Stellenbosch University GIS Dictionary. Die naam kan in twee kleure aangebied word met "Stellenbosch University" in grys en "GIS Dictionary" in maroen. Hierdie kleurbenadering volg die voorbeeld van die bestaande studenteportaal. Die woorde "Stellenbosch University" kan 'n hiperskakel wees na die Universiteit se algemene webtuiste. Bo die naam kan (2) die SUNLearn-ikoon geplaas word. Die ikoon kan as hiperskakel dien waar die studente na die studenteportaal kan terugkeer. Hierdie hiperskakels help dat die vakwoordeboek en die ander universiteitsplatforms geïntegreerd kan funksioneer.

Onder die naam is daar (3) die drie skakels. Die eerste skakel neem die gebruiker na die openingskerm (Home), die tweede skakel neem die gebruiker na die primêre gedeelte van die vakwoordeboek $(A-Z)$, en die derde skakel neem die gebruiker na 'n lys van buitekenmerke (Other Resources). Hierdie skakels is funksioneel, maar dit benoem ook die tipes data wat aangebied word en waar om dit te vind. Dit is 'n effektiewe uitleg van die dataverspreidingstruktuur en 'n aanduiding van die data-aanbieding. Dit kan soos ' $n$ inhoudsopgawe in 'n gedrukte woordeboek funksioneer (Gouws 2018b: 230).

Hierdie drie skakels word gevolg deur (4) die soekkassie en (5) die alfabetbalk wat deel van die toegangstruktuur uitmaak. Die soekkassie is nie ' $n$ toegangstruktuurelement nie, maar 'n ruimte waar 'n toegangstruktuurelement geplaas kan word. Die soekkassie en die alfabetbalk werk, uit die ondervinding met die Esri-vakwoordeboek, baie effektief. Die toegangsalfabet maak voorsiening vir 'n numeriese-artikeltrajek en dit word op die alfabetbalk met ' $n$ \#-teken aangedui. Die soekkassie is met verdwynskrif gevul wat vir die gebruiker sê dat sy 'n soekwens daar kan intik. Die soekkassie is aangepas om 'n soekwens met 'n enkele klik (®) uit te vee. PharosAanlyn se soekkassie het hierdie funksie en dit werk baie goed omdat die volgende soektog vinniger geloods kan word. Die ideaal sal wees dat die soekenjin volvorme, akronieme en meerwoordige terme in Afrikaans en in Engels kan herken. Dit sal ook goed wees as die soekenjin spelfoute kan herken en die soekwens met die korrekte spelwyse kan voorstel. 


\subsection{Die openingskerm}

Die openingskerm bevat die woordeboekinleiding en die terugvoerfunksie. Afbeelding 2 bied ' $n$ uitbeelding van hoe die openingskerm kan lyk. Die woordeboekinleiding moet aandui wie die teikengebruikers is, watter gebruiksituasies die woordeboek aanspreek, en watter funksies die woordeboek kan vervul. In die inleiding kan daar gespesifiseer word wie die samestellers van die woordeboek is en ook watter rol hulle gespeel het (leksikograaf, vakspesialis en IT-tegnikus). Daar kan ook gespesifiseer word hoe gereeld die woordeboek opgedateer word. Om te spesifiseer wie die samestellers is en hoe gereeld die woordeboek opgedateer word, sal 'n positiewe invloed op die beeld en die gesag van die vakwoordeboek hê.

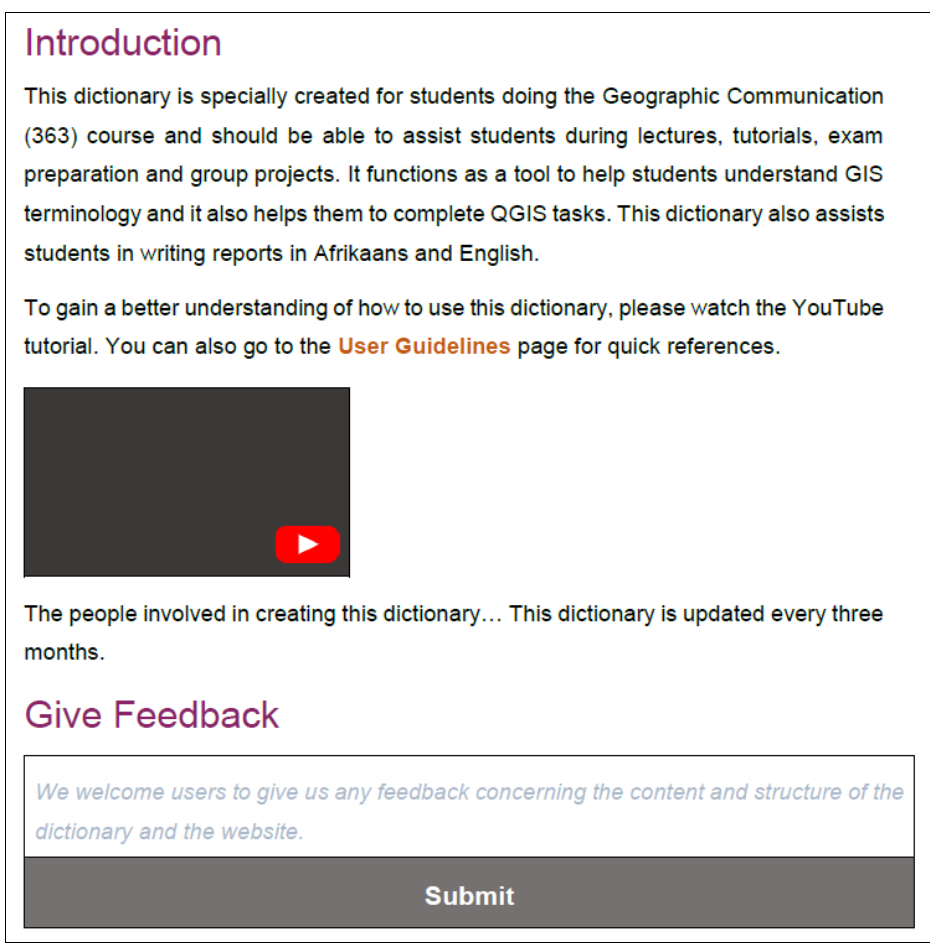

Afbeelding 2: Die openingskerm

Deel van die inleiding is ook die gebruikershandleiding. Die voorstel is om twee tipes gebruikershandleidings te hê. Die eerste is 'n video waarna die gebruiker kan kyk wanneer sy die vakwoordeboek vir die eerste keer gebruik. Die dosent kan ook hierdie video aan die begin van die module in een van die lesings speel. Die tweede gebruikershandleiding kan 'n gedetailleerde geskrewe 
teks wees wat later gebruik kan word as gebruikers sukkel om te onthou hoe ' $n$ sekere deel van die woordeboek funksioneer. Die voorstel is dat hierdie geskrewe gebruikershandleiding op sy eie webblad verskyn en dat daar ' $n$ spesiale soekenjin is wat net op die gebruikershandleiding fokus. Dit sal verseker dat die gebruiker vinnig gehelp kan word indien sy met iets sukkel.

Die terugvoerfunksie kan onder die inleiding geplaas word. Die voorstel is dat die terugvoerfunksie uit ' $n$ kassie bestaan waarin die gebruiker kommentaar kan tik. In die kassie kan daar 'n sin in verdwynskrif staan wat die gebruiker nooi om kommentaar oor die webtuiste en die woordeboekinhoud te lewer. Om die terugvoerfunksie op die openingskerm te plaas, sal 'n aanduiding wees van die samestellers se openlike houding om die woordeboek konstant te verbeter. So 'n openingskerm, met al die bogenoemde fasette, kan die woordeboekvaardighede en die woordeboekkultuur van die studente positief beïnvloed.

\section{3 $\quad$ A tot $Z$}

Volgens Gouws (2018b: 229) is die term "sentrale lys" nie meer van toepassing op aanlyn woordeboeke nie omdat daar nie meer noodwendig 'n "lys" is nie. Hy stel voor dat die term "primêre gedeelte" eerder gebruik word. Die A-Zgedeelte is die primêre gedeelte van die vakwoordeboek en kan wel as 'n lemmalys gegee word. Hierdie lemmalys bevat telkens net die Engelse lemma en die Afrikaanse vertaalekwivalent (sien afbeelding 3).

Die lemma is 'n hiperskakel wat die gebruiker na die betrokke woordeboekartikel lei. Tesame met die hiperskakels word die Afrikaanse vertaalekwivalent ook gegee, want dit sal die gebruiker in sekere situasies tyd kan spaar indien sy nie na die woordeboekartikel hoef te gaan nie. Indien die gebruiker wil sien hoe om die vertaalekwivalent in 'n sin te gebruik, kan sy dan maklik na die artikel gaan. Hierdie aanbieding kan ook moontlik nuttig wees as die gebruiker nie die Engelse term kan onthou nie, aangesien die soekenjin uiteindelik ook Afrikaanse soekwense moet kan opspoor.

Die primêre gedeelte bestaan uit die onderskeie alfabetiese artikeltrajekte. Hierdie lemmalys is een manier waarop die gebruiker deur die vakwoordeboek kan soek as sy iets spesifiek wil naslaan, maar dit kan ook gebruik word as die gebruiker net vir interessantheid deur die vakwoordeboek wil "blaai". Dit is deel van die makrostruktuur, en in effek ook nog deel van die toegangstruktuur.

Die primêre gedeelte bevat ook die permanente kenmerke bo-aan die webbladsy. Aan die onderkant kan daar twee pyltjies wees wat die gebruiker kan gebruik om na die volgende artikeltrajek toe te beweeg. Daar kan ook 'n "terug na bo"-funksie wees wat die gebruiker vinnig kan terugneem na die soekkassie en alfabetbalk bo-aan die webblad. Die "terug na bo"-funksie bestaan uit 'n blokkie aan die regterkant van die skerm waarop die gebruiker kan klik. Hierdie blokkie is soos ' $n$ swewende ballon wat teenwoordig bly selfs wanneer die 
gebruiker op en af oor die teks op die skerm rol. Dit verseker dat die gebruiker altyd maklik toegang tot hierdie funksie het. Die Esri-vakwoordeboek maak gebruik van hierdie funksie en dit spaar die gebruiker tyd en moeite. Afbeelding 3 bied 'n illustrasie van hoe die $A$-Z-gedeelte kan lyk.

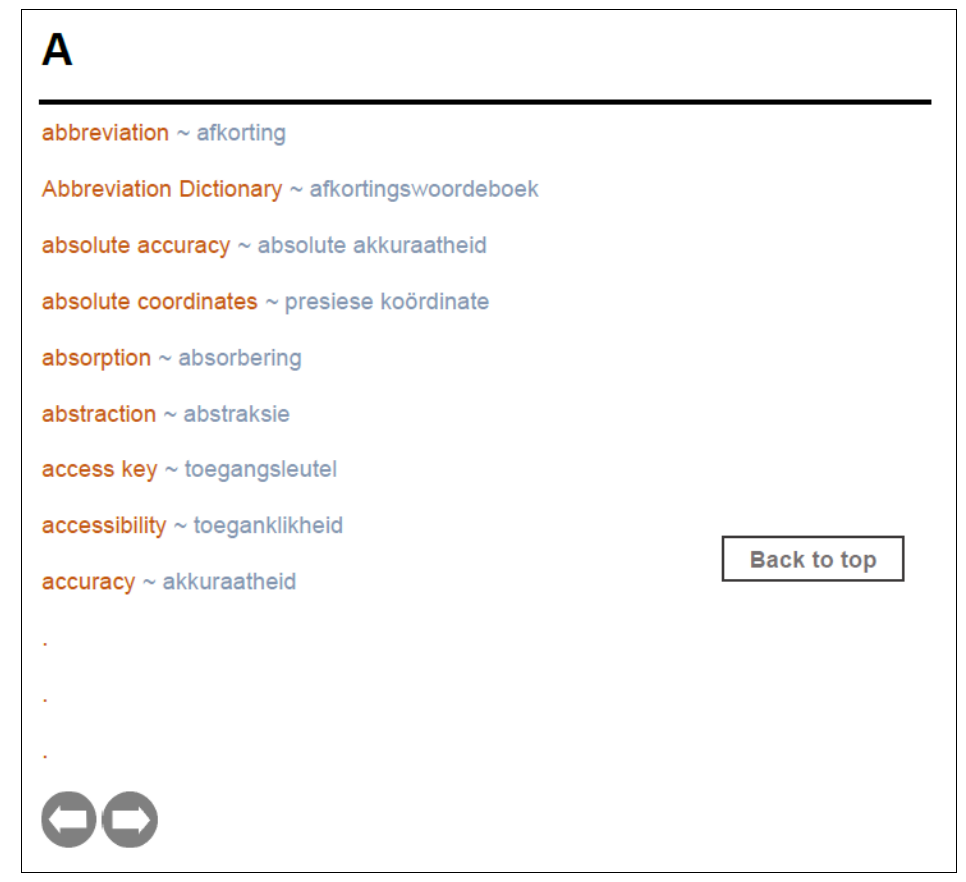

Afbeelding 3: Die A-Z-gedeelte

\section{$2.4 \quad$ Woordeboekartikels}

In die studie is daar ' $\mathrm{n}$ paar tipes data-inskrywings geïdentifiseer wat kan bydra tot die vervulling van die vakwoordeboek se funksie. Tabel 1 en 2 is ' $n$ opsomming van al die verpligte en opsionele data-inskrywings wat geïdentifiseer is (Theron 2019: 71). Verpligte data-inskrywings is dié wat deel van die verpligte mikrostruktuur is, en die opsionele data-inskrywings vorm deel van die uitgebreide verpligte mikrostruktuur. Die verpligte mikrostruktuur bevat al die data-inskrywings wat in ál die artikels belangrik is en die uitgebreide verpligte mikrostruktuur maak voorsiening vir data-inskrywings wat net in sommige artikels verstrek word. (Gouws en Prinsloo 2005: 141). Die artikelinskrywings bestaan uit aanduiders wat funksionele data-inskrywings is, en struktuurmerkers wat gebruikers help om tussen die verskillende aanduiders te onderskei (Du Plessis 2016: 56). 
Tabel 1: Verpligte mikrostruktuur

\begin{tabular}{|l|l|}
\hline Inskrywing & Motivering \\
\hline Lemma & $\begin{array}{l}\text { Vorm deel van die makrostruktuur en is 'n belang- } \\
\text { rike element van die soekproses. } \\
\text { Meerwoordige terme, volvorme en akronieme sal } \\
\text { ook gelemmatiseer word. }\end{array}$ \\
\hline Veld van toepassing & Bied kommunikatiewe hulp t.o.v. teksresepsie \\
\hline Betekenisomskrywing & $\begin{array}{l}\text { Vir teksresepsie, sodat studente kan verstaan wat } \\
\text { van hulle verwag word. }\end{array}$ \\
\hline $\begin{array}{l}\text { Afrikaanse vertaalekwiva- } \\
\text { lent }\end{array}$ & $\begin{array}{l}\text { Bied kommunikatiewe hulp t.o.v. teksproduksie en } \\
\text { vertaling }\end{array}$ \\
\hline Voorbeeldsinne & $\begin{array}{l}\text { Bied kommunikatiewe hulp t.o.v. teksproduksie in } \\
\text { Afrikaans en Engels. }\end{array}$ \\
\hline $\begin{array}{l}\text { Woordsoortklassifikasie } \\
\text { (Werkwoord of Naam- } \\
\text { woord) }\end{array}$ & $\begin{array}{l}\text { Bied kognitiewe hulp, sodat die studente kan ver- } \\
\text { staan wat van hulle verwag word. Bv. "clip" is 'n } \\
\text { werkwoord, want dit is 'n aksie wat uitgevoer moet } \\
\text { word. }\end{array}$ \\
\hline $\begin{array}{l}\text { Verwysing na module- } \\
\text { werk }\end{array}$ & $\begin{array}{l}\text { Kruisverwysings na studiemateriaal kan help sodat } \\
\text { die module meer geïntegreerd met die woordeboek } \\
\text { sal funksioneer. } \\
\text { Sal ondersteuning kan bied tydens toetsvoorberei- } \\
\text { ding. } \\
\text { (Sal ook aanbevelings vir verdere leeswerk gee, } \\
\text { indien nodig.) }\end{array}$ \\
\hline
\end{tabular}

Tabel 2: Uitgebreide verpligte mikrostruktuur

\begin{tabular}{|l|l|}
\hline Inskrywing & Motivering \\
\hline Akroniem & $\begin{array}{l}\text { Vorm deel van die lemma. Dit word in hakies na die } \\
\text { volvorm gegee. }\end{array}$ \\
\hline Illustrasie & Vir teksresepsie \\
\hline Kruisverwysings & Bied kognitiewe hulp. \\
\hline Praktiese toepassings & $\begin{array}{l}\text { Bied operasionele hulp, sodat die studente weet hoe } \\
\text { om 'n opdrag uit te voer. }\end{array}$ \\
\hline Sinonieme & Vir teksresepsie en -produksie \\
\hline
\end{tabular}


Die woordeboekartikels moet gebruik maak van strategieë om die data-aanbieding meer dinamies te maak. Dinamiese woordeboekartikels kan data-oorlading voorkom deur die skermskootstruktuur effektief te gebruik. Die voorstel vir die GIS-vakwoordeboek is om dieselfde data-aanbiedingstrategie te gebruik as die elexiko aanlyn woordeboek (sien afbeelding 4). Dit behels 'n vierkantige teksraam met 'n oortjiekieslys. Die lemma kan direk onder die permanente kenmerke gegee word. Onder die lemma verskyn dan die teksraam met die oortjiekieslys. Soos die gebruiker op 'n oortjie klik, verander die geraamde teks. Hierdie blok-ontwerp help om die data binne die woordeboekartikel georganiseerd te versprei en aan te bied. Dit sal verseker dat daar duidelike, toeganklike soeksones is.

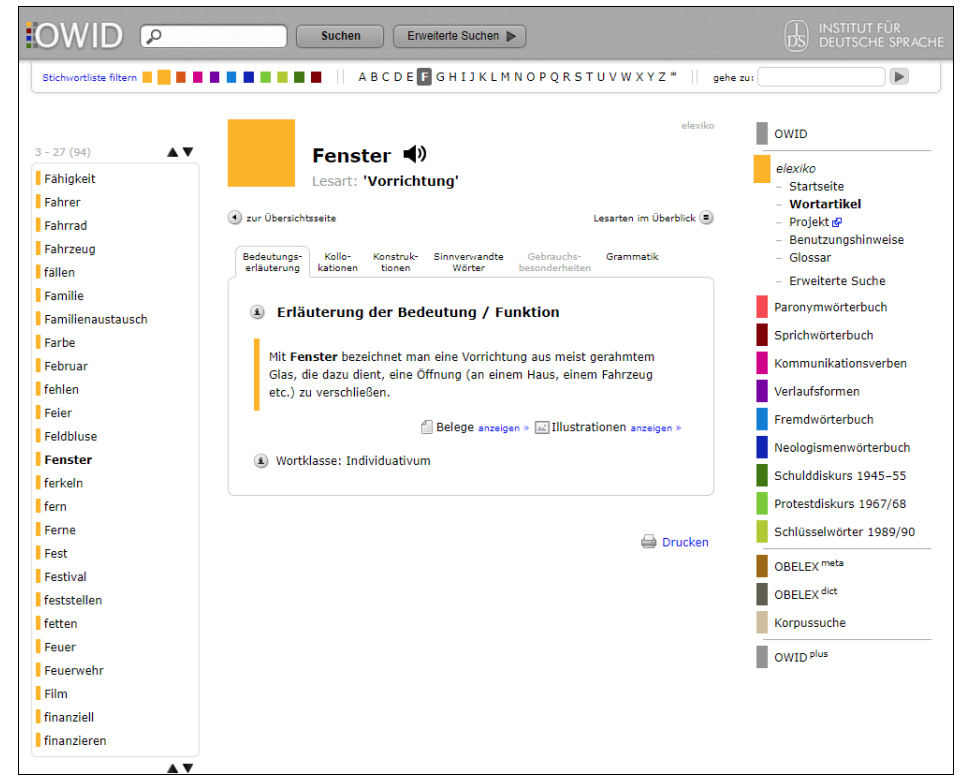

Afbeelding 4: Die data-aanbiedingstrategie van elexiko

Daar kan vier soeksones wees op grond van die kommunikatiewe en operasionele funksie. Buiten die lemma, kan al die ander data-aanduiders binne hierdie vier soeksones verdeel word. Drie van die soeksones hou met die kommunikatiewe funksie verband. Die eerste twee soeksones help die gebruiker met teksresepsie en die derde soeksone bied hulp met teksproduksie. Die vierde soeksone hou met die operasionele funksie verband omdat dit stap-vir-stap-aanwysings gee om 'n sekere taak met die GIS-programmatuur te verrig. Hierdie vier soeksones kan elk gesien word as 'n beperkte woordeboekartikel en saam vorm hulle 'n omvattende woordeboekartikel (Gouws 2018a: 52). Daar is dus vier beperkte woordeboekartikels hier betrokke en hulle word geillustreer in figure 5, 6, 7 en 8 . 
Die data-aanduiders word tussen die vier beperkte woordeboekartikels verdeel, nie net omdat dit die data-tipes funksioneel organiseer nie, maar ook omdat dit die data "filtreer" sodat daar 'n beperkte hoeveelheid data op die skerm vertoon word (Fuertes-Olivera 2016: 237). Dit is nodig sodat die skermskoot effektief gebruik word en net die toepaslike en regte hoeveelheid data vir daardie spesifieke gebruiksituasie gegee word (Fuertes-Olivera 2016: 237). In die inligtingsera van vandag is dit dikwels die geval dat gebruikers nie antwoorde op hul vrae vind nie; nie omdat daar 'n gebrek aan inligting is nie, maar juis omdat daar 'n oorvloed daarvan is. Leksikograwe moet vir die gebruiker die naald uit die hooimied haal.

Omdat aanlyn vakwoordeboeke nie van teksverdigting gebruik hoef te maak nie, kan elk van die struktuurmerkers duidelik benoem word en daar kan selfs spasies oopgelaat word tussen die data-aanduiders (sien afbeelding 5). Die eksplisiete struktuurmerkers veroorsaak dat die gebruikershandleiding van effens minder belang is. Die voorstel is dat die struktuurmerkers in 'n ander kleur gegee word en dat hulle hiperskakels is wat die gebruiker na die gebruikershandleiding kan neem indien daar enige iets is waaroor die gebruiker onseker is. Byvoorbeeld, die data-inskrywing vir woordsoortklassifikasies kan die gebruikers na die handleiding neem en eerstens net verduidelik hoekom hierdie aanduider gegee word, en tweedens ook weer vir hulle verduidelik wat 'n naamwoord en ' $n$ werkwoord is. Die gebruikershandleiding word verder onder afdeling 2.5, wat handel oor die buitekenmerke, bespreek.

\subsubsection{Die eerste beperkte woordeboekartikel}

Die eerste beperkte woordeboekartikel bevat vier tipes data-inskrywings, waarvan die betekenisparafrase die belangrikste is. Die betekenisparafrase-aanduider vertoon 'n verhouding van sekondêre lemmatiese adressering, aangesien die betekenisomskrywing verder weg van die lemma geplaas word wat primêre lemmatiese adressering moeilik maak. Hier gaan dit ook om verwyderde sekondêre lemmatiese adressering, in teenstelling tot onmiddellike adressering waar die adresserende aanduider digby die adres optree. Verwyderde adressering word gebruik omdat die adres (lemma) en die kommentaar wat dit adresseer, 'n groot afstand van mekaar af is.

'n Belangrike aspek om ook in ag te neem, is die vlak van die taal waarin die lemma verklaar word. Die taalgebruik moet nie te moeilik wees vir die gebruiker om te verstaan nie, want die betekenisomskrywing moet nie verdere kommunikatiewe probleme veroorsaak nie. Die samestellers moet ook die beeld van die woordeboek in ag neem as dit by taalgebruik kom. Dit kan problematies wees indien die woordeboek baie formeel is, so ook indien dit té informeel is. Soos reeds genoem is daar drie tipes gebruikers van vakwoordeboeke, te wete die leek, die semideskundige en die deskundige (Du Plessis 2016: 38). Hierdie vakwoordeboek is op semideskundiges gerig en dit moet ook blyk uit die taal waarin die vakwoordeboek geskryf is. Daar is voorts drie taal- 
vlakke vir gebruikers, naamlik beginner, intermediêr en gevorderd. Hierdie vakwoordeboek is op gebruikers met ' $n$ intermediêre taalvlak gemik.

Naas die betekenisomskrywing kan (1) die nodige kruisverwysings, (2) die plek(ke) waar die studente die lemma in die modulewerk kan opspoor, (3) die veld waarop die lemma van toepassing is, en (4) enige sinonieme gegee word. Die onderstaande afbeelding 5 bied 'n uitbeelding van die voorbeeldwoordeboekartikel vir die lemma Digital Elevation Model. Hierdie voorbeeldwoordeboekartikel bevat al die verpligte en opsionele data-inskrywings behalwe die data-inskrywing vir sinonieme.

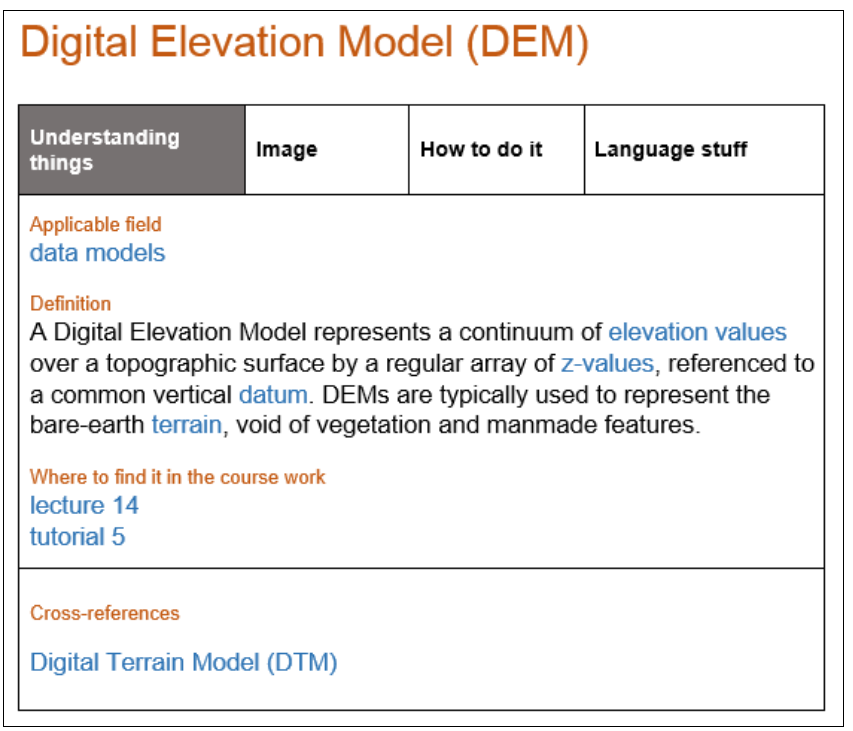

Afbeelding 5: Die eerste beperkte woordeboekartikel

Die vier laasgenoemde data-inskrywings kan ook hiperskakels bevat wat die gebruiker na ander woordeboekartikels of buitekenmeke lei. In die woordeboekartikel vir Digital Elevation Model word aangedui dat die lemma deel vorm van die superordinaat data models. Indien die gebruiker nie verstaan wat met data models bedoel word nie, kan sy dus op die hiperskakel klik om na die woordeboekartikel vir data models geneem te word. Die betekenisomskrywing kan woorde bevat wat as lemmas in die woordeboek opgeneem is en hierdie woorde moet as hiperskakels aangebied word. Die voorstel is ook om die woorde wat hiperskakels bevat in ligblou te merk soos wat die tradisie binne die inligtingstegnologie is.

Dit word beskou as goeie praktyk vir 'n woordeboek om voorsiening te maak vir die gebruik van proskriptiewe notas i.v.m. sinonieme en kruisverwysings, waar nodig (Fuertes-Olivera en Tarp 2014: 224). Daar kan gevalle bestaan waar studente twee terme met mekaar verwar of waar hulle geneig is om die 
term verkeerd te gebruik. Die voorbeeldwoordeboekartikel se betekenisomskrywing gebruik die definisie wat die Esri-vakwoordeboek gee. In die maak van die GIS-vakwoordeboek sal die vakspesialis en die leksikograaf saam moet werk om oorspronklike data te genereer, maar Esri se voorbeeld kan gevolg word. Die Esri-definisie sê kortliks wat 'n digitale hoogtemodel is, en ook waar dit van toepassing is. Sulke notas kan veral gebruik word indien daar verwarring bestaan tussen die Amerikaanse en Suid-Afrikaanse terme, byvoorbeeld die Amerikaanse term 3D feature teenoor die Suid-Afrikaanse term 3D object.

\subsubsection{Die tweede beperkte woordeboekartikel}

Die tweede beperkte woordeboekartikel bevat net die illustrasieprent en ook die bron waar die illustrasieprent gekry is (sien afbeelding 6). Die illustrasieprent word op sy eie aangebied omdat dit die beste manier is om die skermskoot te benut. As dit as deel van die eerste beperkte woordeboekartikel aangebied word, sal daar te veel data in die een skermskoot moet pas. Die illustrasieprent is ook 'n opsionele data-inskrywing. Dit beteken dat die hele beperkte woordeboekartikel ook weggelaat kan word, sonder dat dit nodig is om die artikelstruktuur van die eerste beperkte woordeboekartikel aan te pas.

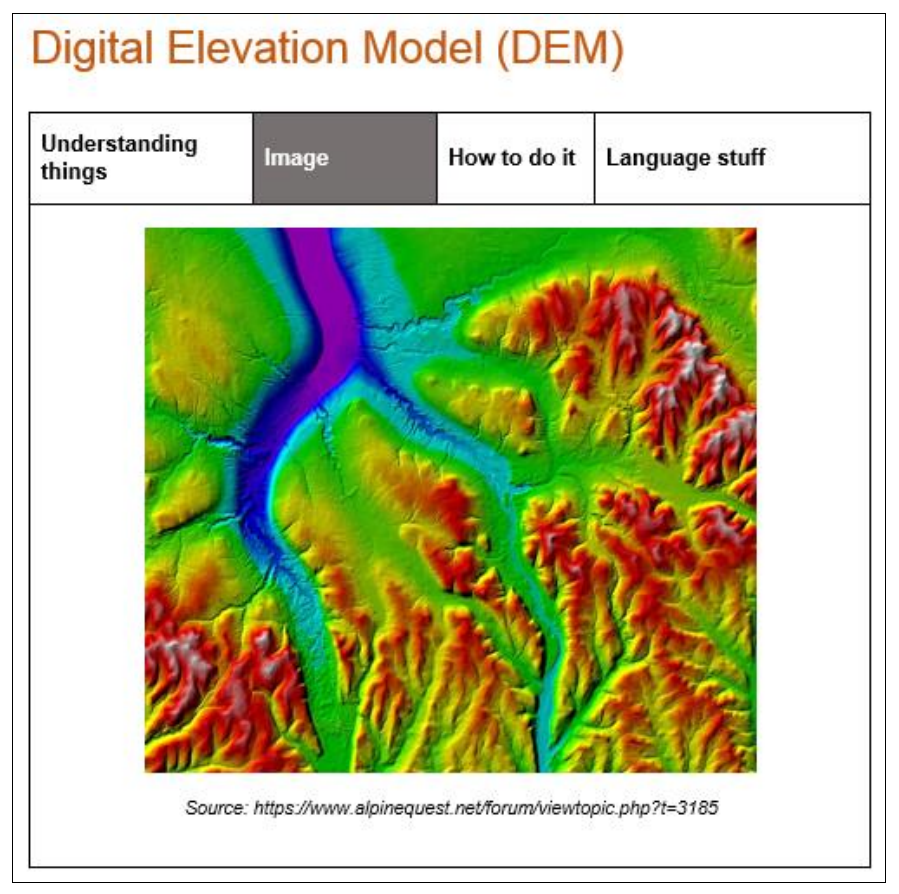

Afbeelding 6: Die tweede beperkte woordeboekartikel 


\subsubsection{Die derde beperkte woordeboekartikel}

Die derde beperkte woordeboekartikel is op die operasionele funksie gerig. Hier kan die data-inskrywings vir die woordsoortklassifikasie en die instruksies vir praktiese toepassing geplaas word. Die beperkte artikel vir die operasionele funksie (How to do it) kan net weggelaat word by die woordeboekartikels waar dit nie van toepassing is nie. In die meeste gevalle is dit wel die geval dat selfs naamwoorde 'n beperkte artikel vir die operasionele funksie benodig, aangesien naamwoorde (veral in hierdie veld) immers steeds gepaard gaan met praktiese toepassings. In die geval van die DEM-woordeboekartikel (afbeelding 7) kan die aksie "create a DEM" geïdentifiseer word.

\begin{tabular}{|c|c|c|c|}
\hline \multicolumn{4}{|c|}{ Digital Elevation Model (DEM) } \\
\hline $\begin{array}{l}\text { Understanding } \\
\text { things }\end{array}$ & Image & How to do it & Language stuff \\
\hline \multicolumn{4}{|l|}{$\begin{array}{l}\text { Part of speech } \\
\text { Noun }\end{array}$} \\
\hline \multicolumn{4}{|c|}{$\begin{array}{l}\text { QGIS instructions } \\
\text { In the } 363 \text { course, you are not required to create a DEM. However, you } \\
\text { are sometimes asked (in tutorial } 5 \text { and } 6 \text { ) to create hillshade using a } \\
\text { DEM-layer. Instructions to do this are described in the dictionary article } \\
\text { for hillshade. }\end{array}$} \\
\hline
\end{tabular}

Afbeelding 7: Die derde beperkte woordeboekartikel.

Die instruksies vir praktiese toepassing in die DEM-woordeboekartikel (afbeelding 7), dui aan dat daar word nie van studente in die Geografiese Kommunikasie-module verwag word om 'n digitale hoogtemodel te maak nie, maar dat hulle wel so 'n model moet gebruik om bergskaduwees te teken. Die volgende sin lui: "Instructions to do this are described in the dictionary article for hillshade". Die behoud en gebruik van leksikografiese terme (soos "dictionary article") word aangemoedig. Enige leksikografiese terme kan van hiperskakels voorsien word wat na 'n afdeling in die gebruikershandleiding lei waarin die terme verduidelik word. Op hierdie manier kan gebruikers se woordeboekvaardighede verbeter, wat ook 'n positiewe invloed op die woordeboekkultuur van die gebruikers hê.

\subsubsection{Die vierde beperkte woordeboekartikel}

Die vierde beperkte woordeboekartikel bevat die data-inskrywings wat gebrui- 
kers met teksproduksie en vertaling kan help. Die Afrikaanse vertaalekwivalent word gegee, en ook Engelse en Afrikaanse voorbeeldsinne. Sekere besluite oor die hantering van Afrikaanse vertaalekwivalente sal vooraf geneem moet word, aangesien daar terminologie sal wees waaroor daar nog nie Afrikaanse vertaalekwivalente bestaan nie. Daar sal gevalle wees waar die Engelse terme nie noodwendig ' $n$ direkte vertaling in Afrikaans het nie, met ander woorde waar 'n ekwivalentverhouding van zero-ekwivalensie geld. In so 'n geval moet die leksikograaf van surrogaatekwivalente gebruik maak. Surrogaatekwivalensie is wanneer die term in Afrikaans beskryf word en 'n voorstel vir 'n vertaalekwivalent kan gemaak word. Sien 'n volledige bespreking van surrogaatekwivalensie in Gouws en Prinsloo (2010).

Die Engelse voorbeeldsin wat volledig in Afrikaans vertaal word, kan vir die gebruiker illustreer hoe sy die term in take en opdragte kan gebruik. Die voorbeeldsinne moet ook geskryf word om inhoudelik verhelderend ten opsigte van die betekenis van die lemma te wees. Sien die voorbeeldsinne in die DEMwoordeboekartikel in afbeelding 8 . Hierdie voorbeeldsinne sou ook deur 'n gekwalifiseerde vertaler vertaal kon word. In hierdie beperkte artikel kan daar ook deurgaans hiperskakels gegee word na die Engelse en Afrikaanse skryfriglyne, wat ook funksioneel tot teksproduksie bydra. Afrikaanse skryfriglyne kan die gebruikers, byvoorbeeld, help met die gebruik van hoof- en kleinletters.

\begin{tabular}{|c|c|c|c|}
\hline $\begin{array}{l}\text { Understanding } \\
\text { things }\end{array}$ & Image & How to do it & Language stuff \\
\hline \multicolumn{4}{|c|}{$\begin{array}{l}\text { Afrikaanse vertaalekwivalent } \\
\text { digitale verhogingsmodel (DVM) }\end{array}$} \\
\hline \multicolumn{4}{|c|}{$\begin{array}{l}\text { Certain types of raster models, especially Digital Elevation Models } \\
\text { (DEMs), allow you to gain more insight into the terrain that they } \\
\text { represent. }\end{array}$} \\
\hline \multicolumn{4}{|c|}{$\begin{array}{l}\text { Sekere rastermodelle, veral digitale verhogingsmodelle (DVM), gee vir } \\
\text { jou meer insig in die terrein wat hulle verteenwoordig. }\end{array}$} \\
\hline \multicolumn{4}{|c|}{ English Writing Guidelines } \\
\hline \multicolumn{4}{|c|}{ Afrikaanse skryfriglyne } \\
\hline
\end{tabular}

Afbeelding 8: Die vierde beperkte woordeboekartikel 
Die bogenoemde vier beperkte woordeboekartikels kan nie die volle bewerking van die lemma op een skermskoot gee nie, maar saam vorm hulle 'n omvattende woordeboekartikel wat die lemma volledig bewerk (Gouws 2018a: 53). Tog kan elk van die skermskote beperkte woordeboekartikels genoem word, want hulle voldoen aan die vereistes van 'n artikel. Dit bevat, met ander woorde, 'n lemma en 'n geordende stel aanduiders wat aan daardie lemma geadresseer is.

\subsection{Buitekenmerke}

Buitekenmerke vorm 'n belangrike deel van die toepassing van die dataverspreidingstruktuur. In die buitekenmerke word data gegroepeer wat die logiese, eenvormige uitleg van 'n woordeboekartikel sou ontwrig, maar wat steeds belangrik is om bepaalde gebruikersbehoeftes te bevredig. Tabel 3. is ' $n$ opsomming van die agt buitekenmerke wat na afloop van die eerste twee take van die studie geïdentifiseer is. Al die buitekenmerke moet aan die werklike doel en funksie van die vakwoordeboek voldoen.

Tabel 3: Nuttige buitekenmerke van 'n GIS-vakwoordeboek

\begin{tabular}{|l|l|}
\hline Buitekenmerke & Motivering \\
\hline Gebruikershandleiding & $\begin{array}{l}\text { 'n Kort video om gebruikers se woordeboek- } \\
\text { vaardighede te bevorder, en 'n geskrewe hand- } \\
\text { leiding vir naslaanwerk. }\end{array}$ \\
\hline Sistematiese inleiding tot GIS & Bied kognitiewe hulp. \\
\hline Eksamenvoorbereiding & $\begin{array}{l}\text { Bied kommunikatiewe hulp en ook ondersteu- } \\
\text { ning met selfstudie. } \\
\text { So 'n buiteteks kan dalk uit meer as een deel } \\
\text { bestaan. }\end{array}$ \\
\hline Navorsingsvoorstelle & Bied kommunikatiewe en kognitiewe hulp. \\
\hline Engelse skryfriglyne & Bied kommunikatiewe hulp t.o.v. teksproduksie. \\
\hline Afrikaanse skryfriglyne & Bied kommunikatiewe hulp t.o.v. teksproduksie. \\
\hline $\begin{array}{l}\text { Skakel na aanlyn taalwoorde- } \\
\text { boeke op die Universiteit se } \\
\text { biblioteekwebtuiste. }\end{array}$ & $\begin{array}{l}\text { Bied kommunikatiewe hulp t.o.v. teksresepsie } \\
\text { en teksproduksie. }\end{array}$ \\
\hline Bronnelys & Verwysings na die korpus. \\
\hline
\end{tabular}

'n Gebruikershandleiding is nie meer so belangrik vir 'n aanlyn woordeboek soos wat dit vir die gedrukte woordeboek is nie (Klosa en Gouws 2015: 171). 
Dit word nietemin ingesluit omdat die gebruikershandleiding die leksikografiese én die tegniese aspekte van die woordeboek kan dek. Volgens een van die dosente in die vakgebied met wie daar 'n onderhoud gevoer is oor die teikengebruikers se behoeftes en vaardighede (Theron 2019: 66), is die daar word vermoed dat hulle woordeboekvaardighede ook nie goed is nie. Die inleidingsvideo moet vir die gebruiker demonstreer hoe die vakwoordeboek werk, maar dit moet ook baie duidelik binne die konteks van die gebruiksituasies geplaas word. Op daardie manier kan dit gebruikers aanmoedig om wel die woordeboek te gebruik.

'n Sistematiese inleiding tot GIS bied kognitiewe en kommunikatiewe hulp, want dit kan gebruikers help om op 'n sistematiese manier die vakgebied wat die onderwerp van die woordeboek is, te leer ken en te verstaan (FuertesOlivera 2009: 162). Hierdie tipe buitekenmerk kan GIS-studente help om die vakgebied te verstaan as hulle, byvoorbeeld, moet begin voorberei vir die eksamen en ook as hulle opdragte en werkstukke moet voltooi (Fuertes-Olivera 2009: 163). Die dosent kan ook die sistematiese inleiding gebruik as voorgeskrewe leeswerk vir 'n lesing aan die begin van die module. Die woordeboek word dan 'n geïntegreerde leerinstrument. Die inleiding moet spesifiek geskryf word vir die studente as teikengebruikers. Dit sal beteken dat die samestellers die taalgebruik en die omvang van die inhoud in die lug van die behoeftes van die gebruikers moet oorweeg. Die jong gebruikers sal, byvoorbeeld, dalk meer aanklank vind by 'n inleidingsvideo as by ' $n$ geskrewe handleiding.

Daar word voorgestel dat die sistematiese inleiding op twee maniere aangebied word, eerstens as 'n kort oorsig en tweedens as 'n meer omvattende weergawe. Hierdie inhoud moet ook op sy eie webblad aangebied word en van 'n inhoudsopgawe voorsien word. Fuertes-Olivera (2009: 166) dui aan ook dat 'n sistematiese inleiding van genommerde paragrawe of opskrifte gebruik moet maak, dat die betrokke terme in vetdruk verskyn, en dat die hele teks geïntegreerd met die lemmalys en woordeboekartikels moet optree. Daar moet dus kruisverwysings vanuit die woordeboekartikels na die buitekenmerk wees en ook andersom. Die internet en inligtingstegnologie maak dit moontlik om inligting op interessante, dinamiese en aantreklike maniere aan te bied. Die Esri-vakwoordeboek het 'n afdeling "What is GIS" wat gesien kan word as 'n sistematiese inleiding (https://www.esri.com/en-us/what-is-gis/overview\#image1). Dit stel 'n goeie voorbeeld wat toekomstige vakwoordeboeke gerus kan volg. Dit is wel jammer dat hierdie sistematiese inleiding nie geïntegreerd optree met die Esri-vakwoordeboek nie.

Die eksamenvoorbereiding- en navorsingsvoorstelle-buitekenmerke is geïdentifiseer na die afloop van 'n ondersoek na die gebruikers se behoeftes (Theron 2019: 66). Die ondersoek dui daarop dat is die studente se taal- en skryfvaardighede in eksamensituasies baie swak is. Die eksamenvoorbereiding kan gevolglik ' $n$ teks wees waarin studente riglyne ontvang oor hoe om vrae te beantwoord, en daar kan ook 'n reeks voorbeeldvrae en -antwoorde wees. Studente kan moontlik beter punte behaal en ook die werk beter verstaan as hulle gewys word hoe ' $n$ goeie antwoord op 'n moontlike vraag lyk. Dieselfde geld 
vir die navorsingsvoorstelle (Theron 2019: 67). Die betrokke studente het nog nie voorheen 'n navorsingsvoorstel gedoen nie, dus sou riglyne en selfs voorbeelde van afgehandelde projekte die studente baie help om te begryp presies wat van hulle verwag word. Die eksamenvoorbereiding en navorsingsvoorstelle bied dus ook die nodige akademiese ondersteuning.

Die Afrikaanse en Engelse skryfriglyne kan studente help met navorsingsvoorstelle en ook met die verslag wat as deel van 'n groot projek inlewer moet word. Die Afrikaanse skryfriglyne kan ook van hulp wees vir studente wat kleiner opdragte in Afrikaans wil skryf. Dit sal hulle help om die Afrikaanse vertaalekwivalente effektief te gebruik. Daarby word ook voorgestel dat ' $n$ skakel voorsien word om gebruikers na al die taalwoordeboeke op die Universiteit se biblioteekwebtuiste te neem. Dit kan 'n nuttige hulpbron wees tydens opdragte, maar ook indien daar probleme ondervind word met (algemene) terme wat nie in die vakwoordeboek opgeneem is nie. Byvoorbeeld, 'n Gebruiker met Engels as tweede taal mag dalk sukkel om die woord "continuum" in die betekenisomskrywing van die DEM-woordeboekartikel (afbeelding 5) te verstaan, en sou die term moontlik in 'n algemene taalwoordeboek sou naslaan.

Die laaste tipe buitekenmerk is die bronnelys. Hierdie bronnelys sal die betroubaarheid van die woordeboek verhoog. Die bronnelys kan dan 'n skakel wees tussen die gebruiker en die korpus. Hierdie bronnelys kan gebruik word om verdere leeswerk of inligting te soek. Daar sal nog verdere navorsing gedoen moet word om die beste manier te bepaal waarop bonverwysing deel van die woordeboekartikel emaak kan word, al dan nie. Dit moet ook hier genoem word dat, alhoewel hulle nie hier bespreek word nie, die skakels na SUNLearn en na die Universiteit se webtuiste ook as buitekenmerke kan geld.

Die uitleg van die bladsy Other Resources kan op so 'n manier aangebied word dat die naam van elke buitekenmerk in alfabetiese volgorde gelys word. Hierdie name dien dan as hiperskakels na 'n ander webblad wat die betrokke inligting bevat. Die voorstel is om die inligting op die webblad aan te bied (html-formaat), maar om die gebruiker die opsie te gee om die hele buitekenmerk af te laai as 'n dokument (pdf-formaat) wat uitgedruk kan word. Hierdie opsie is, byvoorbeeld, net relevant ten opsigte van die eksamenvoorbereidingbuitekenmerk. Ander buitekenmerke kan weer goed werk met ' $n$ soekenjin wat gerig is op daardie spesifieke buitekenmerk, byvoorbeeld die gebruikershandleiding en die bronnelys.

\subsection{Enkele opmerkings oor die korpus}

Die korpus is seker een van dié belangrikste aspekte van enige woordeboekprojek. Die model is slegs die uiteindelike koppelvlak waarmee die gebruiker in aanraking kom. Hierdie koppelvlak is die skakel wat daar tussen die gebruiker en die korpus is. Dit werk deur middel van 'n databasis wat data uit die korpus neem en dit vir die gebruiker op 'n manier aanbied wat georganiseerd en maklik verteerbaar is. Die koppelvlak is die aspek waaraan daar in hierdie 
artikel die meeste aandag geskenk is. Dit is egter nie die enigste komponent wat verseker dat 'n gehaltewoordeboek daargestel word nie. As die databasis en korpus swak is, affekteer dit die gehalte van die woordeboek baie negatief.

In dié studie is daar twee webtuistes geïdentifiseer, GISGeography en GIS Lounge (Theron 2019: 93 en 98), wat saam met die studiemateriaal van die Geografiese Kommunikasie-module kan dien as die vertrekpunt van 'n korpus. Fuertes-Olivera en Tarp (2014: 201) beskou die internet as 'n goeie bron, maar met die voorwaarde dat daar "veiligheidsmaatreëls" gestel moet word. Met ander woorde, alle bronne moet dus eers individueel deur die vakspesialis geanaliseer word om te verseker dat die inhoud aan die vereisde gehalte voldoen. Daarna stel Fuertes-Olivera en Tarp (2014: 202) ook voor dat lemmas vir vakwoordeboeke nie volgens die gebruiklike metode van frekwensie geselekteer word nie, maar op grond van relevansie. Daar sal dus op die kennis en ervaring van die vakspesialis staatgemaak word. Gevolglik word dit weer beklemtoon dat die vakwoordeboek van meet af beplan moet word aan die hand van die leksikografieteorie deur 'n span wat uit minstens 'n leksikograaf, 'n IT-tegnikus en 'n vakspesialis bestaan.

\section{Gevolgtrekking}

Hierdie artikel het die belangrikste aspekte van die voorgestelde woordeboekmodel vir 'n GIS-vakwoordeboek bespreek (Theron 2019). Enkele opmerkings oor die korpus en databasis is gemaak, maar daar is veral gekyk na die dataaanbieding en die dataverspreidingstruktuur, asook die toegang- en artikelstruktuur van die vakwoordeboek. Die woordeboekmodel is gebaseer op die gebruikersbehoeftes en funksies wat in die voorafgaande take van die studie geïdentifiseer is (Theron 2019). Na aanleiding van hierdie bevindings, is daar gefokus op 'n kommunikatiewe funksie wat teksresepsie en -produksie, en vertaling insluit. Daar is ook op 'n operasionele en kognitiewe funksie gefokus. Die woordeboekmodel kan as ' $n$ hibridiese model getipeer word omdat dit op 'n kombinasie van 'n verklarende en vertalende woordeboek dui (Gouws en Prinsloo 2005: 55). Daar is bevind dat 'n GIS-vakwoordeboek by 'n sterk soekenjin en dinamiese woordeboekartikels baat. 'n Voorstel vir verdere navorsing behels ondersoeke na die manier waarop toekomstige woordeboeke meer van woordeboek-individualisering gebruik kan maak.

\section{Bronnelys}

\section{Woordeboeke}

elexiko. 2018. [Intyds]. Beskikbaar: https://www.owid.de/artikel/155448/Vorrichtung [11 September 2018].

Esri Support GIS Dictionary. 2018. [Intyds]. Beskikbaar: http://support.esri.com/other-resources/ gis-dictionary [11 September 2018]. 
PharosAanlyn. 2018. [Intyds]. Beskikbaar: https://www-pharosaanlyn-co-za.ez.sun.ac.za/tuis [11 September 2018].

\section{Ander bronne}

Du Plessis, A.H. 2016. ' $n$ Analise van die selfoon-WAT: 'n Grondslag vir die verbetering van selfoonwoordeboeke. Ongepubliseerde M.A.-tesis. Stellenbosch: Universiteit Stellenbosch.

Fuertes-Olivera, P.A. 2009. Systematic Introductions in Specialised Dictionaries. Nielsen, S. en S. Tarp (Reds.). 2009. Lexicography in the 21st Century. In Honour of Henning Bergenholtz: 161-178. Amsterdam/Philadelphia: John Benjamins.

Fuertes-Olivera, P.A. 2016. A Cambrian Explosion in Lexicography: Some Reflections for Designing and Constructing Specialised Online Dictionaries. International Journal of Lexicography 29(2): 226-247.

Fuertes-Olivera, P.A. en S. Tarp. 2014. Theory and Practice of Specialised Online Dictionaries: Lexicography versus Terminography. Berlyn/Boston: De Gruyter.

Gouws, R.H. 2013. Establishing and Developing a Dictionary Culture for Specialised Lexicography. Jesenšek, V. (Red.). 2013. Specialised Lexicography. Print and Digital, Specialised Dictionaries, Databases: 51-62. Berlyn/Boston: De Gruyter.

Gouws, R.H. 2018a. Accessibility, Access Structures and Access Procedures. Jesenšek, V. en M. Enčeva (Reds.). 2018. Wörtherbuchstrukturen zwischen Theorie und Praxis: 35-56. Berlyn: De Gruyter.

Gouws, R.H. 2018b. Expanding the Data Distribution Structure. Lexicographica 34(1): 225-238.

Gouws, R.H. en D.J. Prinsloo. 2005. Principles and Practice of South African Lexicography. Stellenbosch: SUN PReSS.

Gouws, R.H. en D.J. Prinsloo. 2010. Surrogaatekwivalensie in tweetalige woordeboeke met spesifieke verwysing na zero-ekwivalensie in Afrikataalwoordeboeke. Tydskrif vir Geesteswetenskappe 50(4): 502-519.

Klosa, A. en R.H. Gouws. 2015. Outer Features in e-Dictionaries. Lexicographica 31(1): 142-172.

Taalbeleid van die Universiteit Stellenbosch. 2016. [Intyds]. Beskikbaar: https://www.sun.ac.za/english/ Documents/Language/Finale\%20Junie\%20Taalbeleid\%20November\%202016.pdf [28 Januarie 2019].

Tarp, S. 2012. Specialised Lexicography: 20 Years in Slow Motion. Ibérica 24: 117-128.

Theron, L. 2019. ' $n$ Model vir ' $n$ aanlyn vakwoordeboek vir Geografiese Inligtingstelsels (GIS). Ongepubliseerde M.A.-verhandeling. Stellenbosch: Stellenbosch Universiteit. 